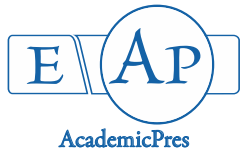

Crisan I and Stoie A (2021)

Notulae Scientia Biologicae 13(1):10838

DOI: $10.15835 / \mathrm{nsb} 13110838$

Research Article

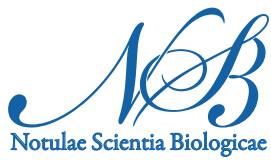

\title{
Seasonal arbuscular mycorrhiza colonization dynamic displays genotype-specific pattern in Iris sibirica L.
}

\author{
Ioana CRIȘAN ${ }^{1}$, Andrei STOIE ${ }^{1,2 *}$ \\ ${ }^{1}$ University of Agricultural Sciences and Veterinary Medicine, Faculty of Agriculture, 3-5 Manastur Street, \\ 400372 Cluj-Napoca, Romania; crisan.ioana@outlook.com; \\ ${ }^{2}$ University of Agricultural Sciences and Veterinary Medicine, Agro-Botanical Garden (CLA), 3-5 Manastur Street, \\ 400372 Cluj-Napoca, Romania; andrei.stoie@usamvcluj.ro (*correspondingauthor)
}

\begin{abstract}
Arbuscular mycorrhiza (AM) is a widespread symbiotic association between plants and Glomeromycota fungi, that brings nutritional-derived benefits for phytobiont. Influence of plant breeding on arbuscular mycorrhiza susceptibility is a topic of current interest that can have many practical implications. Insights into whether new cultivars have a lower mycorrhizal potential, are critical for optimization of AM use. Aim of this research was to conduct a comparative assessment of AM colonization across a phenophase gradient in two Iris sibirica genotypes: one displaying the wild traits versus a modern reblooming cultivar with double flowers. Analysis showed that both Iris sibirica genotypes developed Paris-morphotype. Results indicated that on average the genotype with simple flowers had a higher AM colonization frequency $(84.44 \pm 2.15)$ compared to the new cultivar with double flowers $(52.22 \pm 6.09)$. Significant influence was exercised both by genotype $(p<0.001)$ as well as by phenophase $(p=0.0013)$, over colonization frequency. The genotypes displayed contrasting colonization dynamics: highest AM frequency level occurred in spring for the genotype with simple flowers, and in autumn for the one with double flowers. Results suggest that host metabolic state has regulating role over functionality of established AM-symbiotic association according to plant nutritional requirements, while fungi might also respond to increased or decreased carbon flux in the plant, associated with geophyte phenology.
\end{abstract}

Keywords: cultivar; flower; phenology; root; symbiosis; wild

\section{Introduction}

Iris sibirica L. is a perennial herbaceous plant with rhizomes, native to Eurasia. It thrives in moist soil and tolerates a mildly acidic to alkaline substrate, growing both under semi-shade as well as in full sun conditions. It is considered one of the finest ornamentals for herbaceous border as well as margins of streams, ponds, and lakes (Grey-Wilson, 1997). Wild Iris sibirica can be found growing sporadically in Molinion, Molinio-Arrhenatheretea phytocoenosis throughout Romania (Crișan et al., 2017). Iris sibirica leaves and rhizomes have medicinal properties (Kovalev et al., 2017) while flowers are a source of natural dyes (Kaššák and Kuli, 2014). Also, these plants present phytoremediation capacity for heavy metals (Wang et al., 2018), excess of nutrients (Yang et al., 2017) and some pharmaceutical pollutants (Tejeda and Zurita, 2020).

Received: 29 Oct 2020. Received in revised form: 29 Dec 2020. Accepted: 12 Jan 2021. Published online: 19 Jan 2021.

From Volume 13, Issue 1, 2021, Notulae Scientia Biologicae journal will use article numbers in place of the traditional method of continuous pagination through the volume. 
For Iris sibirica there were fewer breeding programs compared to bearded irises. Many of the Iris sibirica found in cultivation today are tetraploids (Crișan et al., 2017), while interspecific hybrids are not uncommon in gardens, sometimes leading to confusion (Grey-Wilson, 1997; Kaššák, 2013). Traditionally, series Sibericae from section Limniris of the genus Iris, has been divided in two subseries, first one containing Siberian irises with $2 \mathrm{n}=28$ that includes $I$. sibirica and I. sanguinea, as well a second one known as Sino-Siberian irises with $2 \mathrm{n}=40$ (Boltenkov et al., 2020). For a long time, it has been known that Iris sibirica produces fertile hybrids with species from first subseries as well as unfertile hybrids with some species from the second one (GreyWilson, 1997). However, a recent study suggests that species I. sanguinea and I. typhifolia are in fact conspecific with I. sibirica explaining also the overlapping morphological traits (Boltenkov et al., 2020). The breeding trend for irises, including I. sibirica, has been the obtaining of cultivars with wide, ruffled tepals displaying high variation in colours and patterns (Crișan et al., 2017). Cultivated diploid sibs can be distinguished by their delicate stems and narrow leaves, while tetraploids have thicker stems and larger flowers (Kaššák, 2013).

Arbuscular mycorrhiza (AM) is a beneficial partnership for $72 \%$ of vascular plants with fungi from phylum Glomeromycota, that bring many nutrition-related advantages for their host (Brundrett and Tedersoo, 2018). It was estimated that 1000 times more plant species are involved in this symbiosis than fungi species, pointing to low specificity of the mycobiont (Hodge et al., 2010). It is considered that cultivated plants have a lower dependency on AM compared to their wild counterparts (Kokkoris et al., 2019). This is supported by the fact that average mycorrhiza dependency for field crops was shown to be $44 \%$, for forage crops $56 \%$, while for wild grasses and forbs $70 \%$. Also, perennials appear to exhibit a higher mycorrhiza dependency than annuals (Tawaraya, 2003). However, it is important to mention that these were inferred based on studies conducted on a rather limited number of plant species and particularly on Arum-type cultivated plants whereas little attention was given in older works to functional implications of the morphotype diversity across species, as one can see from data available at the time for analysis to Tawaraya (2003). Recent authors remark the poor understanding and knowledge gaps existing in defining more precise the factors that determine symbiotic outcomes for the host plant (Kokkoris et al., 2019). These have important implications, because they hinder the optimization of AM use, due to unpredictability of their effectiveness to enhance traits of interest. A common question heard today is whether during plant breeding history, cultivars developed a lower symbiotic susceptibility compared to their wild counterparts, making them less likely to benefit substantially from AM (Hohmann and Messmer, 2017; Jacott et al., 2017; Liu et al., 2020).

This paper attempts to bring a contribution to the understanding of genotype significance for endomycorrhizal dynamics, adopting a comparison approach by using cultivated Iris sibirica displaying wildtraits versus modern-traits.

Aim of this research was to investigate arbuscular mycorrhiza potential in two cultivated Iris sibirica genotypes: one displaying wild sib traits (simple flower, thin stem, and narrow leaves) and a novel, reblooming cultivar (Iris sibirica 'Concord Crush') displaying modern flower traits such as double flowers and wide tepals.

Two objectives were defined:

- identification of natural susceptibility of the genotypes to arbuscular mycorrhiza

- description of seasonal colonization pattern associated with genotype and phenology.

\section{Materials and Methods}

The experimental plot was located in the Agro-Botanical Garden of University of Agricultural Sciences and Veterinary Medicine from Cluj-Napoca, Romania. Rhizomes were planted in rows, one year prior (2018) to ensure that plants were well established and well-rooted in 2019 when samples were collected for analysis. Space between rows was $40 \mathrm{~cm}$ and between plants per row $20 \mathrm{~cm}$. Rhizomes were watered only until rooting. No fertilizer was applied. Weed control was performed mechanically and manually.

The experiment was organized according to a bifactorial design. 
Factor A with two levels represented by two Iris sibirica genotypes:

$\mathrm{a}_{1}$ - Iris sibirica with simple flowers (Figure 1A) and one blooming/season, from the Iridaceae Collection of the Agro-Botanical Garden USAMV Cluj-Napoca (Index Seminum, 2020);

$\mathrm{a}_{2}$ - Iris sibirica 'Concord Crush' with double flowers (Figure 1B) and rebloomer; this cultivar was created by Bauer and Coble and registered in 2009 (NGA, 2020).

Factor B with three levels represented by contrasting plant phenophase and corresponding to the three months when roots were collected (2019):

$\mathrm{b}_{1}$ - flowering (V - May);

$\mathrm{b}_{2}$ - post-anthesis (VII - July);

$\mathrm{b}_{3}$ - prior to dormancy (IX - September).
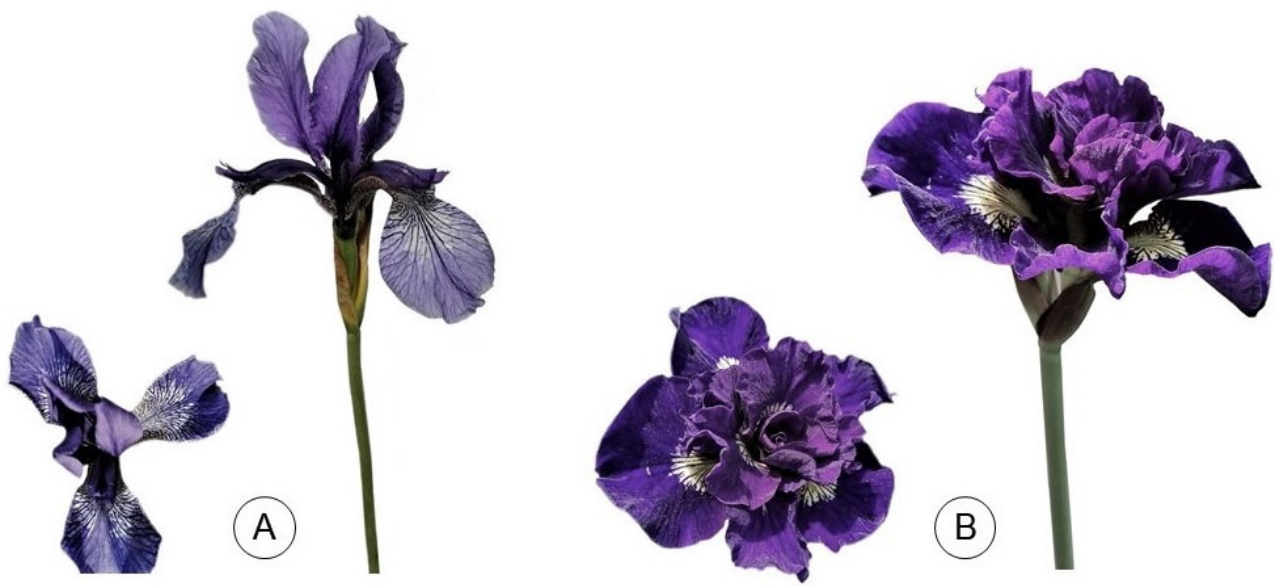

Figure 1. The two Iris sibirica genotypes studied: (1A) with simple flowers, (1B) 'Concord Crush' with double flowers (Original)

Root samples were collected at 2 months intervals: 15 May, 15 July and 15 September 2019 in order to document colonization level during contrasting metabolic states of the plant.

Root samples were stained immediately after collecting, following method of Vierheilig et al. (1998). Stained roots were mounted on glass slides and observed at magnification 100x - 400x under Optika brightfield microscope equipped with condenser 0.90 N.A.

Microscopic evaluation was conducted according to methodology of Trouvelot et al. (1986) and performed on sets of 30 root segments of $1 \mathrm{~cm}$ long in triplicate. In total were analysed under microscope 540 roots $(2$ genotypes $\times 3$ phenophase $\times 30$ roots $\times 3$ replicates $)$. Arbuscular mycorrhizal indicators were obtained using Mycocalc software (INRA, 2001).

Colonization indicators obtained were:

$\mathrm{F} \%=$ frequency of mycorrhizal colonization,

$\mathrm{m} \%=$ intensity of colonization in mycorrhizal parts of root fragments,

$\mathrm{M} \%=$ intensity of mycorrhizal colonization in root system.

Statistical analysis was conducted by applying two-way ANOVA and Duncan test.

Soil in the Agro-Botanical Garden has clay-loam texture, neutral soil $\mathrm{pH}$, low humus level but good NPK content (Crișan et al., 2019).

During the experimental year (2019), the last spring frost occurred in April when plants were in shoot growth phenophase and the highest precipitation levels were registered in May when plants were in bloom. The highest temperature was registered in July $\left(34^{\circ} \mathrm{C}\right)$ when plants were less metabolically active (Figure $2 \mathrm{~A}$ ). By comparing the average annual temperature for 11 years (2008-2018) was observed that the experimental year was $10.78 \%$ warmer and $26.23 \%$ drier than the average for the past decade (Figures 2A, 2B). 


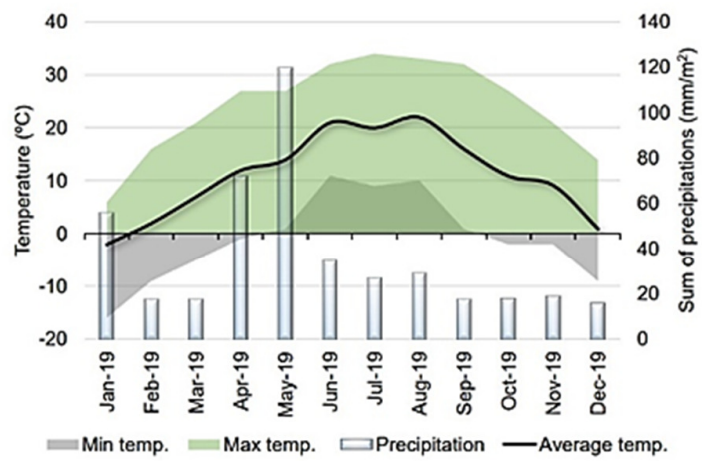

(A)

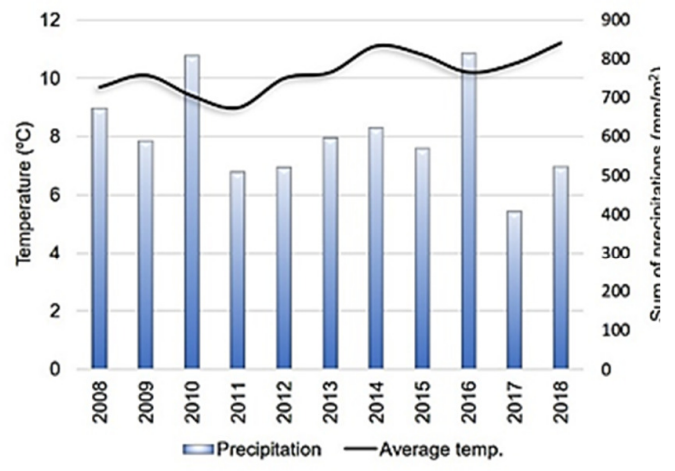

(B)

Figure 2. Climatic conditions during: (2A) the experimental year 2019, (2B) previous decade 2008-2018. Cluj-Napoca climate database (2019a, b) (https://en.tutiempo.net/climate, https://www.wunderground.com)

\section{Results}

In the experimental year, phenological stages of Iris sibirica were: the start of shoots emergence in April, flowering in May and lasting until early summer only for the cultivar with double flowers, summer resting between June to August for both, fruit formation over the summer months only for the genotype with simple flowers, growth occurring again in September for both genotypes, leaf senescence and dormancy onset in October, dormancy from November until March. In the climate of Cluj-Napoca both genotypes maintained green foliage over the summer, but the rebloomer did not produce flowers again in autumn, because the autumn was short with cool nights, and frost occurred starting with October (Figure 2A).

Analysis of variance revealed that genotype exercised a highly significant influence only on frequency of colonization (Table 1) explaining 65\% of variance registered by this indicator (Figure 3). Phenophase exercised a significant influence on both frequency of colonization as well as intensity of colonization in mycorrhizal parts of root fragments (Table 1). Phenophase also explained over $70 \%$ of the variance registered by intensity indicators (Figure 3).

Table 1. Influence of experimental factors and their interaction on arbuscular mycorrhiza (AM) frequency

(F\%) and intensity (m\%, M\%) of colonization for Iris sibirica (2019, Cluj-Napoca)

\begin{tabular}{|c|c|c|c|c|c|c|}
\hline $\mathrm{AM}$ & Factors and interaction & $\begin{array}{l}\text { Mean } \\
\text { square }\end{array}$ & $F$ & $p$ & Sig. & $s^{2}$ \\
\hline \multirow{3}{*}{$\mathrm{F} \%$} & Genotype (G) & 4672.54 & 112.96 & $<0.001$ & $* * *$ & \multirow{3}{*}{451.35} \\
\hline & Phenophase (P) & 505.47 & 12.22 & 0.0013 & $* *$ & \\
\hline & Interaction $(\mathrm{G} \times \mathrm{P})$ & 746.54 & 18.04 & 0.0002 & *** & \\
\hline \multirow{3}{*}{$\mathrm{m} \%$} & Genotype $(\mathrm{G})$ & 2.32 & 0.39 & 0.5404 & $\mathrm{~ns}$ & \multirow{3}{*}{17.94} \\
\hline & Phenophase $(\mathrm{P})$ & 30.11 & 5.14 & 0.0244 & $*$ & \\
\hline & Interaction $(\mathrm{G} \times \mathrm{P})$ & 86.12 & 14.71 & 0.0006 & *** & \\
\hline \multirow{3}{*}{ M\% } & Genotype $(\mathrm{G})$ & 5.31 & 1.46 & 0.2494 & ns & \multirow{3}{*}{8.42} \\
\hline & Phenophase (P) & 7.56 & 2.08 & 0.1670 & ns & \\
\hline & Interaction $(\mathrm{G} \times \mathrm{P})$ & 39.57 & 10.91 & 0.0020 & ** & \\
\hline
\end{tabular}

Note: Two-way ANOVA; $p>0.05$ (n.s.), $p<0.05\left({ }^{*}\right), p<0.01\left(^{* *}\right), p<0.001\left(^{(* *}\right)$

Interaction between genotype and phenophase exercised a significant influence on all three mycorrhizal indicators analysed (Table 1). 


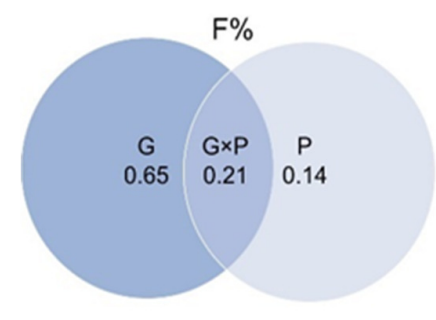

(A)

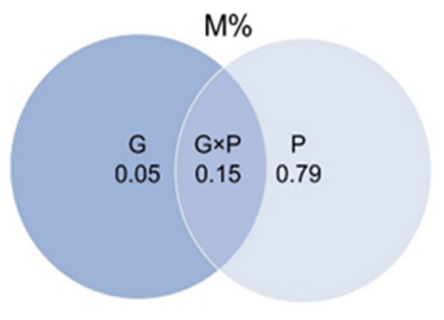

(B)

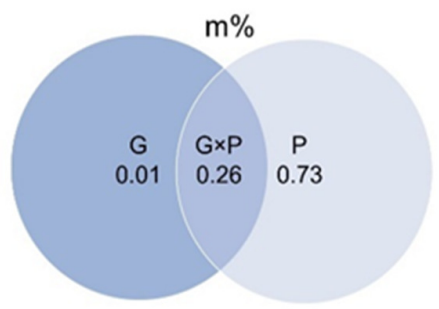

(C)

Figure 3. Venn diagrams expressing partitioning of variance $\left(\right.$ values $\left.\eta^{2}\right)$ : share of factors $(\mathrm{G}=$ genotype, $\mathrm{P}=$ phenophase) and their interaction to overall variance for (3A) AM frequency of colonization, (3B) AM intensity in root system and $(3 \mathrm{C}) \mathrm{AM}$ intensity in mycorrhizal parts of root fragments

Average frequency of AM colonization in 2019 was significantly higher for the Iris sibirica genotype with simple flowers compared to the one with double flowers, while differences between the two genotypes for intensity of colonization in root fragments and root system were not significant (Table 2). This suggests that Iris sibirica with simple flowers presented a higher number of colonization sites in the root system possibly due to a higher susceptibility compared to the genotype with double flowers, but at the colonization sites the distribution of mycorrhizal structures inside cortex tissue was similar for the two genotypes.

Table 2. Combined effect of experimental factors on arbuscular mycorrhiza arbuscular mycorrhiza (AM) frequency (F\%) and intensity (m\%, M\%) of colonization for Iris sibirica (2019, Cluj-Napoca)

\begin{tabular}{|c|c|c|c|c|}
\hline \multirow{2}{*}{ Experimental factors } & \multicolumn{3}{|c|}{ Colonization indicators \pm SE } \\
\hline Genotype & Month & F\% & $\mathrm{m} \%$ & $\mathrm{M} \%$ \\
\hline \multirow{3}{*}{ Simple flower } & $\mathrm{V}$ & $87.78 \pm 4.84 \mathrm{a}$ & $7.72 \pm 2.52 \mathrm{~b}$ & $6.59 \pm 1.82 \mathrm{ab}$ \\
\cline { 2 - 5 } & VII & $80.00 \pm 0.00 \mathrm{ab}$ & $4.64 \pm 1.09 \mathrm{bc}$ & $3.69 \pm 0.89 \mathrm{~b}$ \\
\cline { 2 - 5 } & IX & $85.55 \pm 4.01 \mathrm{a}$ & $6.46 \pm 1.61 \mathrm{~b}$ & $5.45 \pm 1.26 \mathrm{ab}$ \\
\hline \multirow{3}{*}{ Double flower } & V & $30.00 \pm 3.33 \mathrm{~d}$ & $1.40 \pm 0.23 \mathrm{c}$ & $0.43 \pm 0.11 \mathrm{c}$ \\
\cline { 2 - 5 } & VII & $57.78 \pm 4.84 \mathrm{c}$ & $13.38 \pm 0.73 \mathrm{a}$ & $7.80 \pm 1.08 \mathrm{a}$ \\
\cline { 2 - 5 } & IX & $68.89 \pm 2.94 \mathrm{bc}$ & $6.20 \pm 1.02 \mathrm{~b}$ & $4.24 \pm 0.62 \mathrm{~b}$ \\
\hline Simple flower & Overall 2019 & $84.44 \pm 2.15$ & $6.28 \pm 1.02$ & $5.24 \pm 0.81$ \\
\hline Double flower & Overall 2019 & $52.22 \pm 6.09$ & $6.99 \pm 1.78$ & $4.16 \pm 1.12$ \\
\hline
\end{tabular}

Note: Different letters between values denote significant differences (Duncan test, $p<0.05$ )

The seasonal pattern of colonization was different between the two genotypes:

- Iris sibirica genotype with simple flowers presented highest AM frequency and intensity in May, values decreased in July and increased again in autumn (Table 2).

- Iris sibirica with double flowers presented lowest frequency of colonization in spring. Frequency increased in July and reached highest level in September. However, intensity of colonization although was also lowest in spring, it reached the highest levels in July, not in autumn (Table 2).

AM colonization morphology in both Iris sibirica genotypes corresponded to Paris-type (Figure 4). 

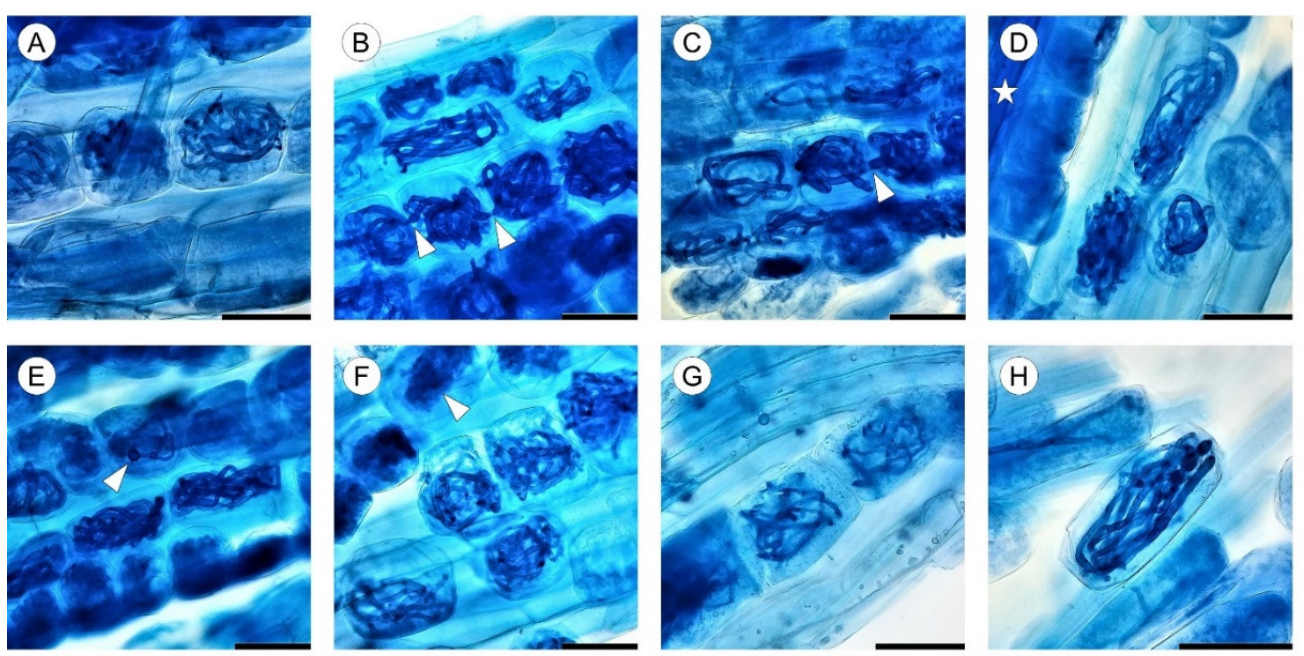

Figure 4. Arbuscular mycorrhiza morphology in Iris sibirica stained roots: (4A-H) typical Paris morphotype displaying intra-cellular hyphae coils, scale bar $=50 \mu \mathrm{m} ;(4 \mathrm{~B}, 4 \mathrm{C})$ arrows - hyphae passing point from one cell to another; (4D) star - localization of vascular bundle in root; (4E) arrow - swelling of intracellular hyphae as incipient stage of spore or vesicle formation; (4F) arrow - digested endomycorrhiza structures; (4A-F, 4H) I. sibirica with double flowers ('Concord Crush'), (4G) I. sibirica with simple flowers

\section{Discussion}

The mycorrhiza pattern observed can be associated with phenology and with corresponding plant metabolic state. Thus, Iris sibirica with double flowers presented a gradual increase of colonization frequency towards autumn because it is a rebloomer and in a milder climate it would produce flowers again in autumn. Thus, higher frequency of colonization in September could signify increased nutrient requirements. By comparison, Iris sibirica with simple flowers followed the typical spring geophyte phenology (as of the wild $I$. sibirica) by entering summer resting at post-anthesis, fact also reflected by decreased frequency of colonization over the warm months accompanied by yellowing of the very tip of the leaves.

Based on these results, it can be deduced that firstly there might be a relationship between the metabolic activity of the plant and the level of root colonization. This would further infer that plant has a role in regulating the functionality of an established symbiotic mechanism according to nutritional requirements, while fungi might also respond to increased or decreased carbon flux in the plant. Despite the altered phenology through plant breeding of rebloomers a synchronization between AM frequency and metabolic state of the plant can be observed just as in the case of the genotype displaying wild traits.

Similar AM Paris-morphotype identified in this study for Iris sibirica was reported before in Iris stolonifera (Zubek et al., 2011) and Iris germanica (Crișan et al., 2019). This morphotype is characterized by spreading of hyphae from cell to cell, without development between cortical cells (Dickson, 2004). This type has been the least studied and therefore less is known about nutrient transfer between symbionts under Paris morphotype compared to Arum-type, with some interesting possibilities proposed recently (Giesemann et al., 2019). The morphotype is controlled mainly by plant genotype, particularly restrictiveness of spaces between cells and to some extent by fungi identity as well (Dickson, 2004; Dickson et al., 2007). Adaptation of the host plant to specific environments might have played an evolutive role in the development of Paris morphotype by certain groups of plants (Giesemann et al., 2019). Spreading of mycorrhiza inside roots in the case of Paris 
morphotype is slow compared to Arum type (Cavagnaro et al., 2008; Giesemann et al., 2019), and this might have an influence on the temporal dynamic of the colonization.

The synchronization between colonization dynamic and phenology observed in Iris sibirica from this study, could be explained at least in part by geophytic lifestyle of the host plant. Because arbuscular mycorrhizal fungi take up to $20 \%$ of assimilated C from the host plant (Konvalinková et al., 2017), and since geophytes function under an efficient system of resource allocation by having to partition carbon fixed through photosynthetic activity between symbiont, host metabolic activity and storage organ, it was suggested that geophytes might be more sensitive to carbon expenditure (Crișan et al., 2018). Below-ground C partitioning by the plant is expected to vary during growing season (Ven et al., 2019), but the role played by AM in C allocation by the host according to phenophase could hold the keys to better understanding in-plant $\mathrm{C}$ dynamics, particularly in geophytes. And for this reason, it is proposed that geophytes might be suitable model plants for the study of these mechanisms.

Arbuscular mycorrhiza interaction was not generally considered during plant breeding programs (Jacott et al., 2017). The fact that Iris sibirica genotype displaying wild traits had higher susceptibility to AM colonization compared to the new cultivar in this study is in accordance with studies on other plant species. Thus, a study has shown a decrease of mycorrhizal responsiveness in modern wheat cultivars compared to older ones (Zhu et al., 2001). Also, domesticated legumes were shown to have fewer symbionts, including AM than wild ones (Liu et al., 2020). These have prompted recent authors to stress the need to no longer ignore the relation between soil microbial players, such as arbuscular mycorrhiza and plants, in order to ensure that new created cultivars, or genotypes taken in cultivation are equipped to benefit from ecosystem services these microorganisms can provide (Hohmann and Messmer, 2017; Jacott et al., 2017).

\section{Conclusions}

On average Iris sibirica displaying wild traits had higher frequency of AM colonization (84.44 \pm 2.15$)$ compared to the new cultivar with double flowers $(52.22 \pm 6.09)$. However, in both cases the pattern was synchronized with plant metabolic state respectively with phenophase.

We propose that mycorrhizal susceptibility to be taken into consideration in plant breeding programs. Iris sibirica developed Paris-morphotype of colonization, similar to I. stolonifera and I. germanica reported in literature. Considering this is the least studied AM morphotype the results bring a contribution to the understanding of colonization dynamics for Paris-type plants.

\section{Authors' Contributions}

Conceptualization: IC, Formal analysis: IC; Investigation: IC; Resources: AS; Supervision: AS; Writing - original draft: IC; Writing - review and editing: AS. Both authors read and approved the final manuscript.

\section{Acknowledgements}

This research received no specific grant from any funding agency in the public, commercial, or not-forprofit sectors. 


\section{Conflict of Interests}

The authors declare that there are no conflicts of interest related to this article.

\section{References}

Brundrett MC, Tedersoo L (2018). Evolutionary history of mycorrhizal symbioses and global host plant diversity. New Phytologist 220:1108-1115. https://doi.org/10.1111/nph.14976

Boltenkov E, Artyukova E, Kozyrenko M, Erst A, Trias-Blasi A (2020). Iris sanguinea is conspecific with I. sibirica (Iridaceae) according to morphology and plastid DNA sequence data. PeerJ 8:e10088. https://doi.org/10.7717/peerj.10088

Cavagnaro T, Smith FA, Lorimer MF, Haskard KA, Ayling SM, Smith SE (2008). Quantitative development of Paristype arbuscular mycorrhizas formed between Asphodelus fistulosus and Glomus coronatum. New Phytologist 149:105-113. https://doi.org/10.1046/j.1469-8137.2001.00001.x

Cluj-Napoca climate database (2019a). Retrieved 2020 October 20 from https://www.wunderground.com

Cluj-Napoca climate database (2019b). Retrieved 2020 October 20 from https://en.tutiempo.net/climate

Crişan I, Vidican R, Stoian V, Stoie A (2017). Wild Iris spp. from Romanian meadows and their importance for ornamental plant breeding. Romanian Journal of Grassland and Forage Crops 16:21-32. https://www.cabdirect.org/cabdirect/abstract/20183119145

Crișan I, Vidican R, Stoian V, Sandor M, Stoie A (2018). Arbuscular mycorrhizae of five summer geophytes from Cluj county. Scientific Papers Agronomy Series 61(1):61-66. http://www.uaiasi.ro/revagrois/PDF/20181/paper/11.pdf

Crișan I, Vidican R, Olar L, Stoian V, Morea A, Ștefan R (2019). Screening for changes on Iris germanica L. rhizomes following inoculation with arbuscular mycorrhiza using Fourier transform infrared spectroscopy. Agronomy 9:815. https://doi.org/10.3390/agronomy9120815

Dickson S, Smith FA, Smith SE (2007). Structural differences in arbuscular mycorrhizal symbioses: more than 100 years after Gallaud, where next? Mycorrhiza 17:375-393. https://doi.org/10.1007/s00572-007-0130-9

Dickson S (2004). The Arum-Paris continuum of mycorrhizal symbioses. New Phytologist 163:187-200. https://doi.org/10.1111/j.1469-8137.2004.01095.x

Giesemann P, Rasmussen HN, Liebel H., Gebauer G (2019). Discreet heterotrophs: green plants that receive fungal carbon through Paris-type arbuscular mycorrhiza. New Phytologist 226:960-966. https://doiorg/10.1111/nph.16367

Grey-Wilson C (1997). Series Sibericae. In: White B, Bowley M, Brearley C et al. (Eds). A guide to species irises their identification and cultivation. Cambridge University Press, Cambridge, United Kingdom, pp 142.

Hodge A, Helgason T, Fitter AH (2010). Nutritional ecology of arbuscular mycorrhizal fungi. Fungal Ecology 3(4):267273. https://doi.org/10.1016/j.funeco.2010.02.002

Hohmann P, Messmer MM (2017). Breeding for mycorrhizal symbiosis: focus on disease resistance. Euphytica 213:113. https://doi.org/10.1007/s10681-017-1900-x

Index Seminum (2020). Hortus Agro-Botanicus Napocensis, Academic Pres, pp 7-8.

INRA (2001). Mycocalc software. National Institute for Agricultural Research Dijon. Retrieved 2020 October 22 from https://www2.dijon.inrae.fr/mychintec/Mycocalc-prg/download.html

Jacott CN, Murray JD, Ridout CJ (2017). Trade-offs in arbuscular mycorrhizal symbiosis: disease resistance, growth responses and perspectives for crop breeding. Agronomy 7:75. https://doi.org/10.3390/agronomy7040075

Kaššák P (2013). Screening of presence of the chosen anthocyanin colorants in the Limniris group Irises. Preliminary Communication of 8th Croatian \& 8th International Symposium on Agriculture, Dubrovnik, Croatia, pp 383387. http://sa.agr.hr/pdf/2013/sa2013_p0409.pdf

Kaššák P, Kuli M (2014). Dyeing potential of the Iris sibirica L. flowers. $2^{\text {nd }}$ Annual International Interdisciplinary $\begin{array}{llll}\text { Conference, } & \text { Azores, } & \text { Portugal. } & \text { AIIC }\end{array}$ http://www.eujournal.org/index.php/esj/article/view/4163/3999.

Kokkoris V, Hamel C, Hart MM (2019). Mycorrhizal response in crop versus wild plants. PLoS One 14(8): e0221037. https://doi.org/10.1371/journal.pone.0221037 
Konvalinková T, Püschel D, Řezáčová V, Gryndlerová H, Jansa J (2017). Carbon flow from plant to arbuscular mycorrhizal fungi is reduced under phosphorus fertilization. Plant and Soil 419(1-2):319-333. https://doi.org/10.1007/s11104-017-3350-6

Kovalev V, Mykhailenko O, Krechun A, Osolodchenko T (2017). Antimicrobial activity of extracts of Iris hungarica and Iris sibirica. Annals of the Mechnikov Institute 2:57-64.

Liu A, Ku YS, Contador CA, Lam HM (2020). The Impacts of domestication and agricultural practices on legume nutrient acquisition through symbiosis with rhizobia and arbuscular mycorrhizal fungi. Frontiers in Genetics 11:583954. https://doi.org/10.3389/fgene.2020.583954

NGA (2020). The National Gardening Association. Plant Data Base. Retrieved 2020 October 23 from https://garden.org/plants/view/232413/Siberian-Iris-Iris-Concord-Crush/

Tawaraya K. (2003). Arbuscular mycorrhizal dependency of different plant species and cultivars. Soil Science and Plant Nutrition 49(5):655-668. https://doi.org/10.1080/00380768.2003.10410323

Tejeda A, Zurita F (2020). Capacity of two ornamental species (Iris sibirica and Zantedeschia aethiopica) to take up, translocate, and accumulate carbamazepine under hydroponic conditions. Water 12:1272. https://doi.org/10.3390/w12051272

Trouvelot A, Kough JL, Gianinazzi-Pearson V (1986). Estimation of vesicular arbuscular mycorrhizal infection levels. Proceedings of the $1^{\text {st }}$ European Symposium on Mycorrhizae, Dijon, France.

Ven A, Verlinden MS, Verbruggen E, Vicca S (2019). Experimental evidence that phosphorus fertilization and arbuscular mycorrhizal symbiosis can reduce the carbon cost of phosphorus uptake. Functional Ecology 33(11):2215-2225. https://doi.org/10.1111/1365-2435.13452

Vierheilig H, Coughlan AP, Wyss URS, Piché Y (1998). Ink and vinegar, a simple staining technique for arbuscularmycorrhizal fungi. Applied and Environmental Microbiology 64:5004-5007. https://doi.org/10.1128/AEM.64.12.5004-5007.1998

Wang Y, Lv N, Mao X, Yan Z, Wang J, Tan W, Li X, Liu H, Wang L, Xi B (2018). Cadmium tolerance and accumulation characteristics of wetland emergent plants under hydroponic conditions. RSC Advances 8:33383-90. https://doi.org/10.1039/c8ra04015j

Yang J, Qi Y, Li H, Xu G (2017). Comparison of nitrogen and phosphorus purification effects of different wetland plants on eutrophic water. ICAESEE IOP Conf. Series: Earth and Environmental Science 113:012042. https://iopscience.iop.org/article/10.1088/1755-1315/113/1/012042

Zhu Y-G, Smith SE, Barritt AR, Smith FA (2001). Phosphorus (P) efficiencies and mycorrhizal responsiveness of old and modern wheat cultivars. Plant and Soil 237(2):249-255. https://doi.org/10.1023/a:1013343811110

Zubek S, Nobis M, Błaszkowski J, Mleczko P, Nowak A (2011). Fungal root endophyte associations of plants endemic to the Pamir Alay Mountains of Central Asia. Symbiosis 54:139-149. https://doi.org/10.1007/s13199-011-0137$Z$
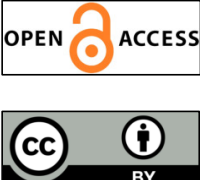

The journal offers free, immediate, and unrestricted access to peer-reviewed research and scholarly work. Users are allowed to read, download, copy, distribute, print, search, or link to the full texts of the articles, or use them for any other lawful purpose, without asking prior permission from the publisher or the author.

License - Articles published in Notulae Scientia Biologicae are Open-Access, distributed under the terms and conditions of the Creative Commons Attribution (CC BY 4.0) License.

(c) Articles by the authors; SHST, Cluj-Napoca, Romania. The journal allows the author(s) to hold the copyright/to retain publishing rights without restriction. 